\title{
TRANSPOSIÇÃO INTERMIDIÁTICA: DIÁLOGO ENTRE LITERATURA E CINEMA
}

\section{INTERMEDIA TRANSPOSITION: A DIALOGUE BETWEEN LITERATURE AND CINEMA}

ROSA, Joseana Stringini da ${ }^{1}$

RESUMO: O presente trabalho propõe uma análise da graphic novel Le bleu est une couleur chaude (2010), de Julie Maroh e do filme La Vie d'Adèle (2013), dirigido por Abdellatif Kechiche, que, no Brasil, recebeu o título de Azul é a cor mais quente. O objetivo é analisar a questão da intermidialidade entre literatura e cinema, bem como dar ênfase para o processo de adaptação, visto que o filme é criado a partir do romance gráfico. Pretende-se também observar a construção da transposição das imagens impressas e a adaptação de uma mídia para outra, do livro para a tela, em seus contrastes e suas similaridades. Para a discussão, parte-se de pressupostos teóricos que possam dar conta da Teoria da Adaptação e da Literatura Comparada, trazendo autores como Linda Hutcheon, Robert Stam, Jeanne-Marie Clerc e Umberto Eco.

PALAVRAS-CHAVE: Azul é a cor mais quente, Graphic Novel, Cinema, Intermidialidade, Adaptação.

ABSTRACT : The present work proposes an analysis of the graphic novel Le bleu est une couleur chaude (2010), by Julie Maroh and the film La Vie d'Adèle (2013), directed by Abdellatif Kechiche. In Brazil, the movie received the title of Azul é a cor mais quente. The objective of this work is to analyze the issue of intermidiality between literature and cinema, as well as to emphasize the process of adaptation, since the film is created from the graphic novel. It is also intended to observe the construction of the transposition of the printed images and the adaptation of one medium to another, from the book to the screen, in its contrasts and similarities. For the discussion, theoretical assumptions are made that can account for the Theory of Adaptation and Comparative Literature, bringing authors like Linda Hutcheon, Robert Stam, Jeanne-Marie Clerc and Umberto Eco.

\footnotetext{
${ }_{1}$ Mestra em Letras pelo Programa de Pós-Graduação em Letras da Universidade Federal de Santa Maria (PPGL/UFSM). Jornalista pela Universidade Franciscana (UFN), de Santa Maria, RS. Atua como pesquisadora com ênfase para as relações entre literatura e fotografia e como professora de cursos e oficinas de fotografia para o público infantil, infanto-juvenil e adulto, bem como em curadorias de exposições fotográficas.

E-mail: joseana.stringini@gmail.com
} 
KEYWORDS: Azul é a cor mais quente, Graphic Novel, Cinema, Intermidiality, Adaptation.

\section{PRIMEIRAS PALAVRAS}

Sucessivas gerações acompanharam nos últimos séculos modificações no âmbito das produções artísticas, culturais e intelectuais. Da representação na pintura à captura de instantes na fotografia. Do congelamento de cenas, do estático aos 24 quadros por segundo, ao movimento, aos frames, no digital. Do cinema mudo ao som e à trilha sonora. Nesse percurso, a literatura também inventa novas maneiras de contar histórias. Novas técnicas surgem na arte da narrativa e recursos típicos do cinema acabam também influenciando a literatura, das longas descrições de espaços ao monólogo interior, aos fluxos de consciência das personagens. Têm-se, a partir do século XIX (com o surgimento da fotografia e do cinema), a reinvenção de espaços e tempos, bem como o emprego de novos efeitos nas narrativas tanto literárias quanto visuais e cinematográficas.

O questionamento sobre a fidelidade de uma obra adaptada surge no debate entre a literatura e os trabalhos de adaptações para o cinema. Como se trata de linguagens, mídias e suportes diferentes, o resultado, portanto, será de uma nova cópia, ou melhor, um novo produto cultural. A transposição intermidiática - da literatura para o cinema - apresenta um diálogo entre duas linguagens, verbal e visual, com o uso de determinadas técnicas que possam dar conta da adaptação. Características próprias da literatura podem ser encontradas no cinema de forma a, não somente, somar, mas multiplicar as possibilidades do intercâmbio dessas narrativas.

O presente trabalho tem como objetivo analisar o diálogo entre literatura e cinema e a transposição intermidiática das obras em análise, assim como observar os caminhos percorridos pela transposição e os mecanismos empregados na adaptação de uma mídia, de um suporte para outro. Visto que uma nova linguagem é criada, a partir de uma narrativa literária, pretende-se abordar a forma como esse "novo" é apresentado trazendo para a discussão teóricos que possam dar conta da Teoria da Adaptação e da Literatura Comparada como Linda Hutcheon, Robert Stam, Jeanne-Marie Clerc e Umberto Eco. Como objetos de análise, têm-se a graphic novel Le bleu est une couleur chaude (2010), de Julie Maroh e o filme - uma adaptação - La Vie d'Adèle 
(2013), dirigido por Abdellatif Kechiche, que, no Brasil, recebeu o título de Azul é a cor mais quente, conforme o título do livro.

Inicialmente, o presente artigo busca apresentar um aporte teórico que possa dar conta da questão da intermidialidade envolvendo literatura e cinema e as teorias da adaptação para em seguida apresentar o corpus do trabalho - romance gráfico e filme. Por meio da análise das obras e do método comparativo, busca-se demonstrar os contrastes e as similaridades entre ambas. Como resultado inicial, observa-se a transposição de narrativas não como cópia fiel, mas como intercâmbio de gêneros artísticos e a possibilidade da criação de novos olhares, novas narrativas, novos pontos de vista.

\section{TRÂNSITOS INTERMIDIÁTICOS: APONTAMENTOS TEÓRICOS}

A aproximação entre cinema e literatura é frequentemente encontrada e remonta a tempos anteriores ao advento do som na Sétima Arte. A relação entre essas duas linguagens é permeada por influências, ora a literatura influenciando a narrativa cinematográfica, ora o cinema influenciando a narrativa literária. Pode ser percebida, em um primeiro momento, segundo Jeanne-Marie Clerc, uma influência sofrida pela literatura, visto que "o cinema surgia como a arte nova por excelência capaz de realizar essa 'revolução' aguardada por uma grande parte do mundo intelectual do princípio do século" (CLERC, 2004, p. 290). Assim, tem-se o surgimento de uma nova relação entre duas formas de expressão no meio cultural, artístico e intelectual.

Ao se falar desse intercâmbio de gêneros, é necessário ressaltar a importância dos estudos comparatistas e a aplicação de uma análise conjunta entre duas obras, de mídias diferentes. A literatura comparada, com a tarefa de aproximar a literatura de outras formas de expressão, ou mesmo de textos literários entre si, volta-se para uma reflexão em torno da intermidialidade, da intertextualidade, da interdisciplinaridade, conforme explicita Tania Carvalhal (2003):

A literatura comparada é uma prática intelectual que, sem deixar de ter no literário o seu objeto, confronta-o com outras formas de expressão cultural. É, portanto, um procedimento, uma maneira específica de interrogar os textos literários não como sistemas fechados em si mesmos, mas em sua interação com outros textos, literários ou não (CARVALHAL, 2003, p. 48). 


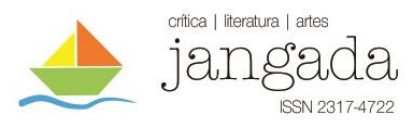

Como um procedimento ou um recurso de análise e de interpretação, os estudos comparatistas surgem como uma forma de explorar os campos de trabalho como um meio e não somente como um fim. Segundo Carvalhal (2003) a ampliação dos estudos comparatistas ocorre com as relações interartísticas a partir de relações múltiplas entre uma obra literária e outros meios de expressão artística. Ampliam-se os procedimentos analíticos e, segundo Carvalhal, "já não é mais a diversidade linguística que serve de base à comparação, mas a diversidade de 'linguagens' ou de 'formas de expressão', próprias e divergentes" (2003, p. 37). Essa possibilidade de mover-se entre várias áreas ressalta a importância da literatura comparada e os seus estudos interdisciplinares.

Os estudos comparados permitem interligar, por exemplo, a literatura e o cinema. Há a presença de uma transposição de um texto literário para uma outra mídia e uma transformação do signo verbal para o signo visual, ou vice-versa. Durante um período, especialmente em tempos que remetem à origem cinematográfica, o cinema passa a ser visto como um grande difusor comercial. Alguns aspectos culturais acabam sendo excluídos devido a um descrédito, ou por se tratarem de objetos da cultura popular ou por serem vistos como produtos de massa, de consumo, produzidos em série, visando unicamente ao lucro. São vistos como uma produção não mais realizada por uma figura individual, por um único gênio criador como na literatura ou mesmo na arte da pintura, por exemplo.

Jeanne-Marie Clerc (2004) sinaliza três momentos na história do cinema em que a figura do escritor está interligada. Primeiramente há um entusiasmo por parte de escritores dos anos 1920 diante de um possível intercâmbio entre o trabalho literário e o trabalho cinematográfico. Já em um segundo momento cria-se uma certa hostilidade a partir do cinema sonoro, com fins comerciais, e, após a Segunda Guerra Mundial, surge um movimento de escritores que estabelecem uma nova relação "já não de influência ou de rivalidade, mas de osmose original entre os dois meios de expressão" (CLERC, 2004, p. 286).

Em determinado momento, escritores passam a frequentar o espaço situado atrás das câmeras buscando adaptar seus escritos, inicialmente criados para serem lidos, como ocorre com Marguerite Duras e Alain Robbe-Grillet. Mas é comum encontrar obras literárias adaptadas para o cinema em que escritores e diretores estão dissociados da tarefa de adaptação. Quando os dois tipos de texto, literário e cinematográfico, não pertencem ao mesmo autor, "corre-se o risco", conforme aponta Clerc (2004), de uma leitura subjetiva que um autor realizará da obra de outro e a possibilidade de criação de uma nova obra. 


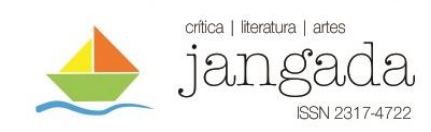

Esse percurso que migra das palavras impressas no livro para as imagens dispostas na tela envolve uma análise que se faz necessária, inicialmente, de abordagem de alguns aspectos específicos de cada meio artístico. A distinção das características próprias de duas formas de arte pode ser pensada a partir das diferenças de signos, conforme aponta Umberto Eco:

o fruidor (na literatura) é provocado por um signo linguístico recebido sob a forma sensível, mas que só pode ser usufruído a partir de uma operação bastante complexa, embora imediata, de exploração do "campo semântico" conectado a tal signo, até o momento em que, sob a escolta dos dados conceituais, o signo também tiver evocado, com acepção apropriada, uma soma de imagens capazes de estimular emocionalmente o receptor. Por outro lado, no caso da estimulação por meio de uma imagem (e é o caso do filme), o percurso é exatamente o inverso: o primeiro estímulo é dado pelo dado sensível ainda não racionalizado e conceitualizado, recebido com toda a vivacidade emocional que comporta (ECO, 2016, pp. 188-189).

No âmbito do diálogo entre a narrativa literária e a narrativa cinematográfica, a intermidialidade pode ser compreendida à luz dos estudos das Teorias da Adaptação. O escritor e cineasta francês Alain Robbe-Grillet (1922-2008) afirmava que escrever um romance ou rodar um filme são "duas atividades perfeitamente separadas" (ROBBE-GRILLET apud CLERC, 2004, p. 284). Ao analisar cinema e literatura e suas relações, percebe-se que a adaptação de uma obra literária para as telas cinematográficas percorre um caminho que vai além de transformar e adaptar linguagens. O cinema traz não apenas uma obrigatoriedade de contar uma história, conforme o texto em que se baseia, na sua integridade, mas traz uma nova forma de contar, de representar e de ver o mundo. Linda Hutcheon (2011) considera o trabalho da adaptação como um processo de criação, que pode envolver uma reinterpretação e uma recriação:

a adaptação é uma transposição anunciada e extensiva de uma ou mais obras em particular. Essa "transcodificação" pode envolver uma mudança de mídia (de um poema para um filme) ou gênero (de épico para um romance), ou uma mudança de foco, e, portanto, de contexto: recontar a mesma histórica de um ponto de vista diferente, por exemplo, pode criar uma interpretação visivelmente distinta (HUTCHEON, 2011, p. 29). 
A fidelidade com a obra original não se faz obrigatória, conforme explicita Hutcheon. As adaptações cinematográficas, apesar de constituírem aspectos essenciais, foram muitas vezes negligenciadas, conforme aponta Clerc (2004, p. 296) ao ressaltar que "parece que elas devem ser estudadas com o mesmo estatuto que têm as traduções". A polêmica, segundo ela, diz respeito ao fato de se destacar a "superioridade do romance sobre o filme" tratando a película como uma "pálida cópia industrial de um gênio criador único" (CLERC, 2004, p. 296). Tem-se, assim, uma visão, por hora equivocada, de que a adaptação cinematográfica é um "subproduto bastardo desta industrialização da cultura própria de uma sociedade que faz comércio com os produtos do espírito tal como com os da agricultura ou das fábricas", sinaliza Clerc.

Se a adaptação fílmica deve ser uma tradução fiel do texto literário, conforme aponta o senso comum, então, a intertextualidade entre a obra literária e a obra cinematográfica ocorreria apenas se o receptor identificasse ou estivesse familiarizado com o texto de partida, com o texto adaptado. Mas é justamente o contrário de uma fidelização e uma integridade ao texto original que Hutcheon discute ao sinalizar para o ato de adaptar como algo não completamente fiel, visto que é "um ato de apropriação ou recuperação, e isso sempre envolve um processo duplo de interpretação e criação de algo novo" (HUTCHEON, 2011, p. 45).

Um produto e uma produção - é dessa forma que uma obra adaptada é vista por Linda Hutcheon, ou seja, uma transposição de uma mídia para outra em que se modificam os suportes e o meios empregados para a sua construção, mas também, ao mesmo tempo, uma nova forma de expressão, que se constrói conforme a interpretação e as próprias escolhas do autor/diretor/roteirista, e, portanto, uma reinterpretação.

Adaptações cinematográficas de romances são muito frequentes, mas não são atividades novas. Remontam a tempos desde a origem do cinema e muitas vezes são/foram vistas como algo inferior, de forma negativa. Ao abordar a questão da fidelidade com que essa obra adaptada deve manter com a obra original, surge uma problemática: torna-se a literatura como superior ao cinema (em casos de adaptações) ao se defender uma integridade do texto-base e uma cópia fiel. À respeito dessa prerrogativa, Robert Stam assinala:

A linguagem tradicional da crítica à adaptação fílmica de romances [...] muitas vezes tem sido extremamente discriminatória, disseminando a ideia de que o cinema vem prestando um desserviço à literatura. Termos como 


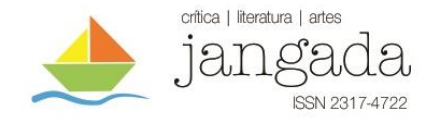

"infidelidade", "traição", "deformação", "violação", "vulgarização", "adulteração" e "profanação" proliferam e veiculam sua própria carga de opróbrio. Apesar da variedade de acusações, sua motriz parece ser sempre a mesma - o livro era melhor (STAM, 2008, p. 20).

Para Stam (2008) não ser fiel à obra, ou seja, ser “infiel”, já carrega nesse próprio termo uma carga negativa. Isso pode ser claramente visto em termos de decepção do receptor, sendo que este, ao expressar-se dessa forma justifica-se com alguns motivos, como o fato de a adaptação não "tocar", nem trazer à tona algumas sensações captadas no livro:

a própria violência do termo - infiel - expressa a grande decepção que sentimos quando uma adaptação fílmica não consegue captar aquilo que entendemos ser a narrativa, temática, e características estéticas fundamentais encontradas em sua fonte literária (STAM, 2008, p. 20).

Transpor para o cinema as mesmas emoções que o receptor recebe somente com o texto literário diz respeito a uma questão enraizada em alguns preconceitos. Há que se levar em consideração algumas informações importantes ao se analisar duas obras, de mídias e linguagens diferentes, como por exemplo: as imagens criadas, inventadas, a imaginação típicas da narrativa literária - e a imagem que aparece pronta aos olhos, na narrativa cinematográfica, visual.

A primeira reação diante da imagem do cinema, segundo Umberto Eco (2016) não é "intelectiva", nem "intuitiva", ela é, antes de tudo, "fisiológica" e essa recepção ocorre da seguinte forma: “a pulsação cardíaca acelerada precede qualquer compreensão e decantação crítica do dado, o esboço de resposta motora revelado pelo encefalograma precede não somente o consenso da inteligência, mas também aquele da imaginação" (ECO, 2016, p. 189). A imagem visual, assim, cria um mecanismo de percepção do mundo distinto do apresentado pelo texto. $\mathrm{O}$ cinema possibilita a junção, em uma única interface, de texto, imagem e som.

\section{DAS PÁGINAS DO LIVRO PARA AS TELAS DE CINEMA}

Eu quero que eles (diários) fiquem com você, neles estão todas as minhas lembranças de adolescência coloridas de azul. Azul-escuro, azul-celeste, azul-marinho, azul Klein, azul ciano, azul ultramarino... O azul se tornou uma cor quente (MAROH, 2013, p. 9).

\footnotetext{
Jangada | nr. 11, jan/jun, 2018 | ISSN 2317-4722 
O longa-metragem francês La Vie d'Adèle, de 2013, chegou às telas de cinema no Brasil com o título Azul é a cor mais quente. O filme, premiado com a Palma de Ouro, no Festival de Cannes, no mesmo ano de lançamento, tem como diretor o franco-tunisiano Abdellatif Kechiche. O enredo conta a história de Adèle (Adèle Exarchopoulos), uma garota com 15 anos de idade que passa por uma fase de amadurecimento e, ao se envolver com Emma (Léa Seydoux), uma estudante de artes, mais velha, descobre sua sexualidade.

O filme é uma adaptação do romance gráfico Le bleu est une couleur chaude, de 2010, da escritora e quadrinista francesa Julie Maroh. Em 2011, o livro recebeu o prêmio Prix du public Fnac-SNCF no $38^{\text {a }}$ Festival Internacional de Quadrinhos de Angoulême, na França. No Brasil, recebeu a tradução de Marcelo Mori e foi lançado em 2013 pela Editora Martins Fontes com o título Azul é a cor mais quente. Com tons de preto e branco e toques de azul, a graphic novel narra uma história que alterna as cenas da adolescência de Clémentine com passagens em que Emma lê os seus diários, após alguns anos, com uma escrita, em sua maioria, linear.

Para a análise das obras (romance gráfico e filme) parte-se do princípio de que, por se tratar de uma adaptação cinematográfica e de que uma obra se baseia em outra, há, entre ambas, algumas particularidades. Os estudos comparatistas permitem empregar como recurso analítico a aproximação de expressões artísticas diferentes, conforme vimos anteriormente. Essa aproximação de obras permite criar um diálogo em que podem ser observadas relações entre literatura e cinema marcadas por contrastes e similaridades, elos e diferenças.

\section{POSSÍVEIS DIÁLOGOS ENTRE AS OBRAS}

"Meu anjo de azul. Azul do céu. Azul dos rios. Fonte de vida" (MAROH, 2013, p. 128).

Nas primeiras páginas do livro, o leitor se depara com Emma lendo páginas do diário de Clémentine, que em suas escritas se despede de seu grande amor. Emma, neste momento, aparece apresentando um grande sofrimento por essa perda. Diferente das primeiras cenas do filme, em que a garota de 15 anos aparece em uma cena corriqueira: sai de casa, corre para pegar o transporte e já dentro do ônibus dorme no caminho em direção à escola. Na sala de aula, alunos leem passagens de livros e, na saída, conversas com as colegas, em que os meninos e os namoros figuram entre os assuntos. 


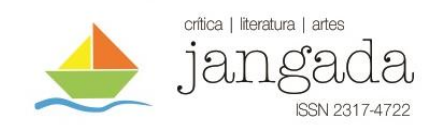

Essas ações da narrativa cinematográfica se passam nos primeiros minutos do filme, contrastando com as primeiras páginas do livro. Grandes diferenças nas narrativas são percebidas na abertura das duas obras. $\mathrm{O}$ filme apresenta uma linearidade em sua fórmula de contar a história, com início, meio e fim, muito bem delimitados. Já na graphic novel, a estruturação do texto narrativo e a sequência dos fatos se dá de forma não-linear, e, portanto, não seguindo uma ordem cronológica. Dessa forma, a narrativa "fisga" e impacta o leitor através desse recurso empregado. Nas primeiras páginas são apresentadas ao leitor cenas de Emma recebendo os diários de Clémentine (que morreu) sendo entregue por seus pais. A partir dessa ação, inicia-se uma história marcada por um tempo cronológico que se alterna com passagens dos diários de Clémentine, lidos por Emma, com cenas que vão e voltam, do presente ao passado.

A personagem principal recebe nomes e destinos diferentes em ambas as narrativas filme e romance gráfico. No filme, conforme o próprio título original indica, a personagem se chama Adèle, ao contrário do livro, em que a garota recebe o nome de Clémentine. Já Emma, a menina de cabelos azuis recebe o mesmo nome em ambas as obras. No que se refere ao desenrolar da história e o destino de Adèle/Clémentine, as visões apresentadas em cada obra também se diferenciam. A personagem da obra original morre de uma hipertensão arterial pulmonar, o que não ocorre na adaptação. Em ambas as obras, o relacionamento entre as duas não ocorre por muito tempo, porém o sofrimento de Emma é enfatizado no romance. A escolha do diretor cinematográfico dá-se por um final triste, porém não trágico (como no romance gráfico em que Clémentine morre). A relação amorosa entre as duas personagens não é mantida por muito tempo, no entanto, Adèle, que tem sua vida marcada por uma profunda mudança com o relacionamento, envolvendo descobertas da sua sexualidade, segue amando Emma apesar desse amor não ser recíproco.

A temática, tanto da graphic novel quanto do filme, vai além de simplesmente contar a história de uma adolescente que se apaixona por uma garota mais velha de cabelos pintados de azul. São obras que apresentam conflitos internos, o preconceito e a intolerância da sociedade diante de um relacionamento homossexual, o medo permanente da reação dos pais caso essa relação seja descoberta, e, portanto, a presença constante da mentira.

Em ambas as obras, mas com maior ênfase no filme, encontram-se as diferenças entre as personagens. Não se trata somente de uma diferença de idade, mas também social, econômica e cultural. As cenas das refeições na casa de Clémentine mostram a família em frente à televisão e a inexistência de diálogos ao se alimentarem da comida preferida dos membros da casa: o 


\section{1 jangada}

espaguete à bolonhesa. Em contraste, o jantar servido pelos pais de Emma: vinho branco, frutos do mar e a preferência da casa, as ostras, que Clémentine compara à "meleca".

Em se tratando do assunto "profissão", ambos os pais das personagens divergem do tema. Para os pais de Clémentine, o fato de Emma estudar Belas Artes é um problema, pois, na opinião deles, é difícil viver de arte e que o ideal seria casar com um marido que trabalhasse, no comércio, por exemplo, para o sustento da casa. Já os pais de Emma ficam surpresos ao saber que Adèle quer ser professora e defendem que ela deva almejar algo maior. Além disso, Adèle, estudante do ensino médio em Literatura, sente-se desconfortável "diante de tanta cultura", ao conhecer os amigos de Emma, estudante do quarto ano de Belas Artes.

Embora, no geral, a adaptação cinematográfica adote caminhos diferentes, algumas cenas são reproduzidas em sua integridade, como os diálogos e os enquadramentos no encontro das protagonistas em um bar, e os planos em que Adèle/Clémentine sonha com a garota de cabelos azuis. No filme, as tomadas de câmera são intercaladas com momentos em que Emma se faz presente e ausente, criando efeitos de devaneios e de sonhos. Já na graphic novel, mãos com coloração azulada aparecem tocando a personagem. A primeira cena de sexo no filme alvo de críticas e discussões - mostra a relação entre as personagens com planos fechados, close-up, com uma duração temporal de aproximadamente sete minutos. No romance gráfico, a primeira relação ocorre em uma sequência de quatro páginas, com alternância de planos, também com ausência de diálogos.

Os tons de azul permeiam ambas as obras, presentes na maioria das cenas. São detalhes em tons azulados, como de uma blusa, uma camiseta, uma roupa, um cachecol, o céu, a parede ao fundo da sala de aula, um objeto decorativo, um cartaz ao fundo escrito bleu, a iluminação do bar, o tom da noite nas ruas. No livro, Clémentine apresenta o azul como sendo a cor que se torna mais quente desde o momento em que se sente atraída por Emma, a garota com o cabelo azul. No entanto, tanto no romance, quanto no filme, Emma aparece com os cabelos pintados com outra cor no momento em que a relação entre ambas "esfria" e as brigas são constantes.

Por fim, pode-se pensar também em uma ligação entre o azul, a cor mais quente, com a pintura. Emma, como estudantes de Artes, apresenta o universo das artes visuais para Adèle. Há a presença de pinturas, esculturas, museus em que elas visitam, ou nas obras feitas por Emma, ao retratar em desenhos ou pinturas, a própria Adèle. No filme, Adèle faz referência à Picasso em dois momentos: "Gosto de pintura, mas não conheço muito. Gosto de Picasso", e "Ele fala de você (Emma) como se fosse Picasso". Embora a proposta do trabalho não abarque as relações entre literatura, cinema e pintura, cabe apontar a questão do azul na obra de Pablo 
Picasso (1881-1973). Em seus anos de formação, Picasso adota o simbolismo. Na fase que ficou conhecida como Fase Azul, Picasso retrata a pobreza, a solidão, as misérias da vida. A melancolia é expressada monocromaticamente em tons de azuis. Esse período que vai de 1901 a 1904 é provocado pelo suicídio de um grande amigo.

\section{CONSIDERAÇÕES FINAIS}

As relações entre cinema e literatura podem ser percebidas ao analisar a adaptação de uma obra para outra, entre o diálogo de diferentes linguagens com aspectos semelhantes e contrastantes. No entanto, há a presença de algo comum no que se refere a estrutura. Segundo Umberto Eco (2016, p. 190-191), ambos os gêneros artísticos são "artes da ação" em que existe "uma relação estabelecida entre uma série de eventos, um desenvolvimento de acontecimentos reduzido à estrutura de base", a partir do sentido apontado na poética aristotélica.

A ação como um eixo em comum, porém a diferença pode ser analisada na forma como essas ações são apresentadas, na narrativa literária e na narrativa fílmica, criando suas próprias linguagens e montagens. A partir de perspectivas diferentes, os autores produzem a sua própria maneira de narrar e, assim, dialogam com a posição de Linda Hutcheon (2011), ao defender que o adaptador se torna um intérprete antes de criar, e que, portanto, além de uma intermidialidade presente na criação a partir de uma obra (neste caso em forma de romance gráfico) para uma outra interface (o cinema), também há interpretação, transposição e produção um novo modo de expressão, conforme a sua visão e percepção.

Essa intermidialidade que ocorre entre literatura e criação cinematográfica dispõe de uma adaptação que pode ser conforme as inspirações do autor, de forma independente e, portanto, não havendo uma obrigatoriedade com o texto em sua íntegra ou uma fidelização com a obra original em que o filme é baseado. Isso pode ser percebido na análise entre o romance gráfico Le bleu est une couleur chaude e o filme La vie d'Adèle: trata-se de duas obras, duas mídias, duas formas de expressão, em que não há a superioridade de uma perante a outra. Há, sim, diferentes obras, diferentes produções com diferentes linguagens, cada uma com suas particularidades.

\section{REFERÊNCIAS BIBLIOGRÁFICAS}


CARVALHAL, Tania Franco. O próprio e o alheio: Ensaio de Literatura comparada. São Leopoldo: Editora UNISINOS, 2003.

CLERC, Jeanne-Marie. "A literatura comparada face às imagens modernas: cinema, fotografia, televisão”. In: BRUNEL, Pierre; CHEVREL, Yves (org.) Compêndio de literatura comparada. Trad. Maria do Rosário Monteiro. Lisboa: Fundação Calouste Gulbenkian, 2004. p. 283-323. ECO, Umberto. A definição da arte. Trad. Eliana Aguiar. Rio de Janeiro: Record, 2016.

HUTCHEON, Linda. Uma teoria da adaptação. Trad. André Cechinel. Florianópolis: Editora UFSC, 2011.

KECHICHE. Abdellatif. Azul é a cor mais quente. França: Wild Bunch, 2013, 1 DVD (180 $\min )$.

MAROH, Julie. Azul é a cor mais quente. São Paulo: Editora Martins Fontes, 2013.

STAM, Robert. A literatura através do cinema. Realismo, magia e a arte da adaptação. Belo Horizonte: Editora UFMG, 2008. 


\section{ANEXOS}

Le bleu est une couleur chaude

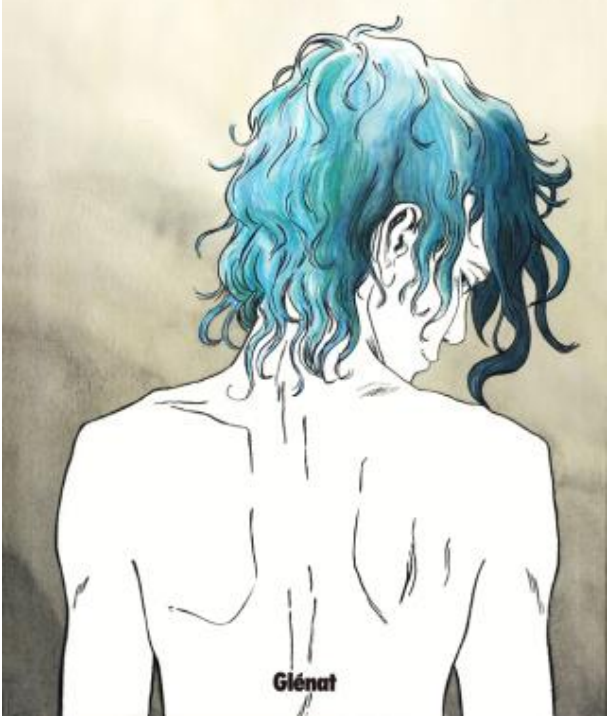

Figura 1: Capa do livro

Le Bleu est une couleur chaude, de Julie Maroh

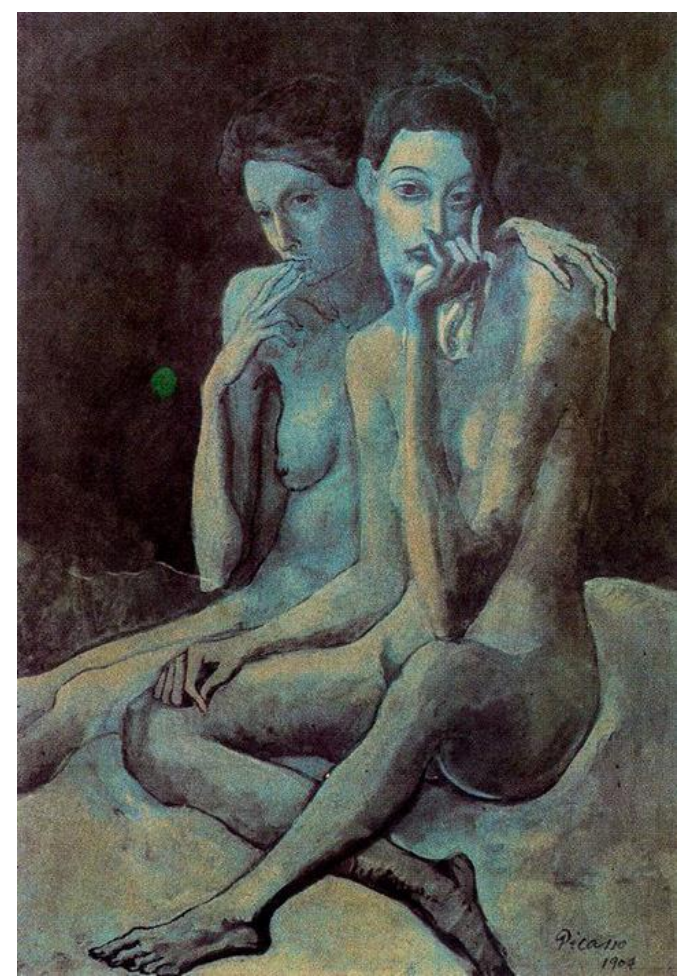

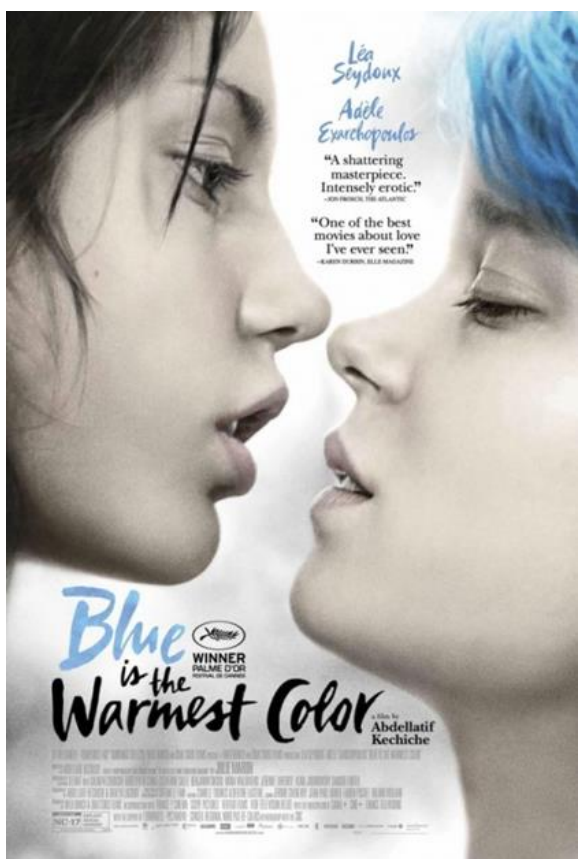

Figura 2: Um dos cartazes do filme

Figura 1 Obra de Pablo Picasso (1904),

Fase Azul 